\title{
HA 2010 Overview
}

\author{
Hyaluronan 2010 オーバービュー
}

\begin{abstract}
Hascall, Vincent C. ${ }^{1}$; Toole, Bryan P. ${ }^{2}$; de la Motte, Carol $^{1}$; Yanagishita, Masaki ${ }^{3}$; and Kimata, Koji ${ }^{4}$
${ }^{1}$ Department of Biomedical Engineering, Lerner Research Institute, Cleveland Clinic, Cleveland, OH 44195, U. S. A.; ${ }^{2}$ Department of Regenerative Medicine and Cell Biology, College of Medicine, Medical University of South Carolina, SC 29425, U. S. A.; ${ }^{3}$ Section of Biochemistry, Department of Hard Tissue Engineering, Graduate School of Medical and Dental Sciences, Tokyo Medical and Dental University, Tokyo 113-8549; ${ }^{4}$ Research Complex for the Medicine Frontiers, Aichi Medical University, Aichi 480-1195
\end{abstract}

Hyaluronan 2010 in Kyoto, June 6-11, was the 8th International Conference on Hyaluronan research and the second sponsored by the International Society for Hyaluronan Sciences (ISHAS). There were more than 300 attendees, 17 Sessions and 160 abstracts. The increasing breadth and depth of research with this fascinating macromolecule were apparent, and this short overview will only outline a few of the presentations to highlight a number of the new advances. The Program and Abstracts of Lectures and Posters are available on the ISHAS website at http://www.ishas.org.

Aimin Wang (Session 1) presented data that show that hyaluronan synthases in intracellular compartments (endoplasmic reticulum, golgi, transport vesicles) are activated by a PKC signaling pathway when mesangial cells divide in hyperglycemic medium. The synthases utilize cytosolic substrates and deposit the newly synthesized hyaluronan in these intracellular compartments, which initiates an endoplasmic reticulum stress driven autophagic response. A large upregulation of cyclin D3 at the end of cell division initiates extrusion of the hyaluronan and the formation of a monocyte-adhesive matrix. Evidence was provided that hyperglycemia in the streptozotocin diabetic rat model initiates mesangial cell division, autophagy and hyaluronan matrix formation in glomeruli by the same mechanism, and that recruitment of inflammatory cells into this matrix is critically involved in subsequent glomerular nephropathy and proteinurea. This mechanism is likely to occur in most cells that divide in hyperglycemia.

Sohkichi Matsumoto (Session 1) described the analysis of the role of hyaluronan after infection with Mycobacterium tuberculosis (MTb). His group found that the major hyaluronan synthase expressed in the lung was HAS1, and the expression of HAS1 increased after the infection. Interestingly, that hyaluronan synthesized by HAS1 and HAS3 but not by HAS2 supports growth of MTb, yet not Mycobacterium avium. The data suggest that pathogenic mycobacteria utilize an intrinsic host-protective molecule, hyaluronan, to grow in the respiratory tract.

Ralf Richter (Session 1) described a new method for
Hyaluronan 2010 (HA2010) は 2010 年 6 月 6 日から 11 日 の期間京都で開催され、これは「第 8 回ヒアルロン酸研究に 関する国際カンファレンス (8th International Conference of Hyaluronan Research)」でもあり、また国際ヒアルロナン学会 (International Society for Hyaluronan Sciences, ISHAS) 主催の 第 2 回目の国際学会でもあった。参加者は 300 名を超え、17セッ ションからなり、アブストラクトも 170 を越えた。ヒアルロ ン酸 (本稿では以降 HA と略する) に関する研究領域の拡大と 深化は明らかであり、本オーバービューでは特にいくつかの 新しい進展について紹介したい。本会のプログラム、講演抄録、 アブストラクトは ISHAS の website、http://www.ishas.org、 に掲載されている。

Aimin Wang (セッション 1) は腎メサンギウム細胞は高グ ルコース培地中で培養すると、細胞内分画 (小胞体、ゴルジ、 輸送小胞)の HA 合成酵素が PKC シグナル経路により活性化 されることを示した。 HA 合成酵素は細胞質中の基質を用い、 新しく合成された HA をこれらの細胞内画分中に蓄積し、さ らにこれが小胞体ストレスとして働きオートファジーを引き 起こした。細胞分裂終期に打ける著明なサイクリン D3 の増加 がHAの分泌を引き起こし単球接着性のマトリックスを形成 させる。ストレプトゾトシン糖尿病ラットを用いた実験系を 用いて、高血糖が同様の機序で、腎メサンギウム細胞の分裂、 オートファジー、HA マトリックスの形成を引き起こすことが 示され、免疫系細胞のこのマトリックスへの浸潤が引き続き 起こる糸球体腎症、タンパク尿に重要な役割を持つことも示 された。またこのような機構は高血糖条件で細胞分裂するほ とんどの細胞で起きているかも知れない。

Sohkichi Matsumoto (セッション1)はMycobacterium tuberculosis 感染症に扔けるHA の役割について報告した。肺 で発現する主要な HA 合成酵素はHAS1 であり、かつ感染後 に上昇するのも HAS1 であった。興味あることに HAS1 及び HAS3により合成されるHA は結核菌の増殖を可能にさせる がHAS2によるものではそうでなかった。この所見は、病原 性の結核菌は元来宿主保護分子として機能する HA を利用し て気道での増殖に利用していることを示唆している。

Ralf Richter ( セッション 1) は固相上の脂質 2 重層に一定 
end-grafting hyaluronan preparations of defined sizes to a solid-supported lipid bilayer, which was used to create well controlled models of thickness and hydration characteristic of pericellular coats. This method was used to determine how different hyaluronan binding proteins can modulate the physical properties of the hyaluronan films. TNFalphastimulated gene 6 (TSG-6) and inter-alpha-trypsin inhibitor (ITI) modify hyaluronan by covalently trans-esterifying the heavy chains from the chondroitin sulfate of ITI to hyaluronan, a process essential for mammalian ovulation. TSG-6 and ITI contracted and mechanically stabilized the hyaluronan films. In contrast, interaction with the cartilage proteoglycan aggrecan greatly increased the film thickness. This method provides an experimental hyaluronan platform that enables quantitative investigation of interactions of hyaluronan binding and modifying proteins, including receptors such as CD44 and LYVE-1, with biologically relevant arrangements of hyaluronan.

Takeshi Fujihara (Session 1) showed the first evidence for the involvement of a hyaluronan-CD44 pathway in regulating orientation of mitotic spindle in normal epithelial cells. Regulation of the orientation is important in normal physiological processes, including epithelial tissue branching and neuron generation by asymmetric cell division. Signals from two distinct surface contact sites are required for the orientation of the mitotic spindle axis in normal epithelial cells. This presentation revealed that high molecular weight hyaluronan-CD44 signaling from the apical and basal surface-membranes regulated the orientation of the mitotic spindle axis by aligning parallel and oblique-perpendicular, respectively, to the basal extracellular matrix.

Four presentations addressed mechanisms for regulating hyaluronan synthases HASs. Toshiya Nakamura (Session 2) described the effects of 4-methylumbelliferone (MU), a known inhibitor of hyaluronan synthesis, and 12-O-tetradecanoylphorbol-13-acetate (TPA) on $O$-glcNAcylation/ phosphorylation of HAS2. The results supported a mechanism in which TPA activation of phosphokinase C phosphorylates HAS2, which in turn increases hyaluronan synthesis. Conversely, $\mathrm{MU}$ inhibits the phosphorylation by stimulating $O$-glcNAcylation of the serine/threonine sites involved in modulating HAS2 activity. Alberto Passi (Session 2) described data supporting this model for regulating HAS activity by directly measuring hyaluronan synthesis by vesicles prepared from plasma and cytosolic membranes after treatments with either phosphatase to remove phosphates, which inhibits activity, or PNGase to remove $O$-glcNAc, which increased activity. He also described experiments with AMPkinase, a key sensor of ATP/ AMP ratios in cells, which specifically inhibits HAS2 and decreases hyaluronan synthesis. This provides a mechanism for inhibiting the use of ATP for synthesis of the UDP-sugar substrates. Evi Heldin (Session 15) described experiments
分子量の HA の分子末端を結合させる新しい方法を報告した。 これにより一定の厚みと水和度を持つ HA 細胞外被モデルを 作ることが可能となる。この方法を用いて各種の HA 結合夕 ンパク質がどのようにHA フィルムの物理学的性状を変化さ せるかの検討を行った。TSG-6 (TNF $\alpha$-stimulated gene 6) お よびITI (inter- $\alpha$-trypsin inhibitor) はHA の化学修飾を行う。 これはITI の heavy chain に対してトランスエステリフィケー ションでコンドロイチン硫酸鎖から HA 転換を行うもので、 哺乳類の排卵機構に必須のものである。TSG-6 および ITI は HA フィルムを収縮させ力学的に安定化させる。これに対して 軟骨プロテオグライカンであるアグリカンはHA フィルムの 厚さを増加させる。本法は CD44 や LYVE1 などの HA 受容体 を含むHA 結合・修飾タンパク質との相互作用を生物学的に 意味ある HA の提示法を使った定量的解析を可能にする。

Takeshi Fujihara (セッション 1) は正常上皮細胞の細胞分 裂紡錘の方向決定に HA-CD44 経路が関与していることを示し た。細胞分裂紡錘の方向決定は上皮組織の分岐や神経細胞形 成など非対称的な細胞分裂を起こす生理的な過程に重要であ る。正常の上皮細胞で細胞分裂紡錘の軸方向を決定するには 2 か所の異なる細胞表面接触からの信号が必要である。本報告 では頂膜及び底膜からの高分子 HA-CD44 結合シグナルが別々 に細胞分裂紡錘の軸方向を決定している、すなわちそれぞれ 底膜における細胞外マトリックスに対して平行にあるいは斜 め-垂直に決定していることが示唆された。

4 つの演題が HA 合成酵素の調節機構について報告した。 Toshiya Nakamura (セッション2) は 4-methylumbelliferon (4-MU)、HA 合成阻害剂として知られている、と TPA (12-O tetradecanoylphorbol-13-acetate) の HAS2 に対する O-GlcNAc 転移/リン酸化に関する影響を報告した。

Alberto Passi (セッション2) は細胞膜掞よび細胞質より 得られた小胞を使い、脱リン酸酵素処理あるいは PNGase を 使って O-GlcNAc を除いた後に直接 HA 合成酵素活性を測定 し、酵素活性の上昇を観察した。また ATP/AMP 比の主要な センサーである AMP kinase が HAS2 を特異的に阻害し、HA 合成を減少させることも示した。これは ATPを使って UDP糖を合成する機構の阻害メカニズムとなり得る。

Evi Heldin ( セッション 15) はHAS2 の lysine 190 の monoubiquitination が酵素活性を減少させること、そして酵素 活性の発現には HAS2 の 2 量体化が必要であることを示した。

Hiroshi Urakawa (セッション7) は乳がん細胞において in 
that showed that mono-ubiquination of lysine 190 in HAS2 suppressed activity, and that dimerization of HAS2 appears necessary for activity. Hiroshi Urakawa (Session 7) described experiments in which MU was shown to decrease hyaluronan synthesis and downregulate mRNA expression of HAS2 in breast cancer cells in vitro. MU also suppressed hyaluronan matrix accumulation and progression of osteolytic tumor lesions in vivo in a bone metastatic mouse model

Bruno Flamion (Session 5) described novel functions of Hyal2, several of which appear to be non-enzymatic. The phenotypic characteristics of Hyal2 null mice on a C57 BL/6 background were detailed and included high plasma HA, enlarged lymphoid organs, and reduced platelet counts. On the cellular level, data were presented that highlighted a role for Hyal2 in the control of pericellular matrix formation and maintenance. In vitro, Hyal2 was found in lipid rafts associated with CD44 and its associated cytoskeleton interacting proteins ezrin-radexin-moesin (ERM). In fibroblast transfection experiments overexpression of Hyal2 was associated with decreased CD44-ERM interaction, as well as reduction in the levels of these proteins. Correspondingly, HA endocytosis and pinocytosis were reduced and stress fiber formation was increased. Additionally, data were presented demonstrating that Hyal2 was important in promoting cell motility and growth in normal cells, but inhibited survival, motility and invasiveness of malignant MDA-MB231 cells. However, Saito et al. (session 6) showed that Hyal2 overexpression induced motility of HeLa-S3 cancer cells via generation of HA fragments, indicating that tumor cell responses are difficult to generalize.

Soren Twarok (Session 6) described the importance of hyaluronan in controlling focal adhesions in esophageal squamous carcinoma cells (ESSCs). Focal adhesions, important for invasive filipodia formation and important in malignant spread, were present in ESSC filipodia. Data demonstrated that ESSCs produce a hyaluronan matrix around their invasive filipodial extensions and that HAS3 was the major synthetic enzyme. Alterations in hyaluronan production by either HAS 3 shRNA treatment or administration of MU reduced filipodia and focal adhesions, and increased degradation of focal adhesion kinase (FAK). Additionally, blocking the RHAMM receptor with: 1) specific antibodies; 2) Pep-1; or 3) RHAMM shRNA resulted in reduced filipodia, FAK cleavage and rapid degradation of focal adhesions. A corresponding reduction in ESSC proliferation was noted. HAS 3 produced hyaluronan in ESSCs, via RHAMM recognition, and induced filipodia and focal adhesions that enhance malignancy. Blocking hyaluronan production and RHAMM recognition of the hyaluronan may be useful in abrogating esophageal cancer invasiveness.

Mark Slomiany (Session 6) discussed the critical role of CD147 (emmprin) in regulation of hyaluronan production and hyaluronan-CD44 signaling. Data were presented vitro 実験で MU が HA 合成を低下させるとともに HAS2 の mRNA を減少させることを見出した。またマウス骨転移モデ ルで、MUはHA マトリックスの蓄積と骨融解性腫瘍の進展 を抑制することを示した。

Bruno Flamion (セッション 5) は Hyal2 の新しい機能に ついて報告した、そのいくつかは酵素活性とは無関係のよう である。C57 BL/6 をバックグランドとした Hyal2 ノックアウ トマウスの表現型では血清 HA の高値、リンパ系器官の肥大、 血小板減少がみられることを報告した。細胞レベルでは Hyal2 が細胞周囲のマトリックス形成、維持に機能していることが 示された。In vitroの系では、Hyal2 はCD44 及びCD44に 付随した細胞骨格結合性タンパクである ERM (ezrin-radexinmoesin) と共にラフトに存在する。トランスフェクションによ り線維芽細胞に Hyal2 を過剩発現させる実験では CD44-ERM 分子間相互作用が減少し、それに従いこれらのタンパクも減 少した。これに相応してHAの細胞内取り込み、飲作用も減 少しストレスファイバーの増加も見られた。さらにHyal2 は 正常細胞の運動性と増殖を上昇させるがMD A-MB231 悪性 細胞の生存、運動性、浸潤性を減少させた。これに反して、 Saito らは (セッション 6) は Hela-S3 がん細胞に扔ける Hyal2 の過剩発現では HA 断片形成による運動性の上昇を見た。

Soren Tworok (セッション6) は食道扁平上皮がん細胞 (ESSCs) でHA がフォーカルアドヒージョンの調節に重要な働 きをしていることを報告した。フォーカルアドヒージョンは 浸潤性の fillipodia 形成及び悪性細胞浸潤に重要であり、ESSC の fillipodiaにも存在している。ESSC は浸潤性の fillipodia 周 囲で抺もにHAS3により合成される。HA マトリックスを形 成している。HAS3 shRNA 処理や MU 処理により HA 合成を 減少させると、fillipodia やフォーカルアドヒージョンを減少 させるとともにFAK (focal adhesion kinase) の分解を立進さ せる。さらに RHAMM 受容体を1) 特異的抗体を使用して、2) Pep-1 を使用して、3) RHAMM shRNA を使用してブロックす ると、それぞれ fillipodia が減少し、FAKの分解、急速なフォー カルアドヒージョンの分解を見る。このような状態では ESSC の増殖は抑えられる。ESSCでHAS3 がHA を合成すると、 RHAMM による認識を介して、fillipodia とフォーカルアドヒー ジョンを形成し細胞の悪性度を高める。 HA の合成掠よび HA の RHAMM による認識を阻害することは食道がん細胞の浸潤 
showing that CD147 and hyaluronan-CD44 interactions act coordinately to regulate assembly and/or stabilization of plasma membrane complexes that include receptor tyrosine kinases and transporters involved in drug resistance and malignant cell properties. Flow cytometry sorting of various tumor cell types was used to yield sub-populations with high and low levels of constitutive CD147 expression. The CD147-high cells demonstrated high levels of invasiveness, anchorage-independent growth and drug resistance as compared to CD147-low cells. The CD147-high cells also expressed higher levels of Has2, CD44, receptor tyrosine kinases, drug transporters and lactate transporters at the plasma membrane. In addition, CD133-positive cancer stemlike cells isolated from human ovarian carcinoma patient ascites expressed similar combinations of proteins at their cell surface. Treatment of the CD133-positive cells with small oligosaccharides of hyaluronan induced dissociation of these complexes and inhibited tumor growth in vivo.

Larry Sherman (Session 9) presented data showing that hyaluronan accumulates in neural stem cell niches and regulates progenitor cell proliferation and differentiation through interaction with CD44. Examination of CD44-null mice showed that these mice express hippocampal learning and memory deficits, consistent with a role for hyaluronanCD44 interactions in this area of the CNS. Additional data were presented showing that progenitor cells entering areas of injury in the CNS express hyaluronidases and that products of hyaluronidase activity promote proliferation and inhibit maturation of progenitor cells. Overall, the data from this group indicate an important role for hyaluronan-CD44 interactions in neural progenitor cell behavior.

Sophia Khaldoyanidi (Session 9) presented data that indicate the importance of hyaluronan in regulating human embryonic stem cell (hESC) differentiation pathways. Hyaluronidase digestion of hyaluronan in hESC cultures decreased the numbers of hematopoietic progenitors and mature hematopoietic cells, and also diminished the numbers of C31+ endothelial cells, stromal fibroblast-like cells and contracting myocytes. Consistent with these results, mRNAs for mesoderm markers (brachyury and BMP2) and for endoderm markers ( $\alpha$-FP and Sox17) were decreased while those for ectoderm markers (GFAP and FGF5) increased.

Tonya Caralla (Session 9) described experiments that show that connective tissue progenitor cells (CTPs) in iliac bone marrow aspirates have pericellular hyaluronan matrices while the large populations of other nucleated cells in the aspirates do not. Magnetic beads coated with a hyaluronan binding protein were used to label the cells, and magnetic separation techniques were used to fractionate them. The CTPs were enriched $\sim 2.7$ fold in a triple pass hyaluronan positive fraction with depletion of the vast
性を減少させるのに意義あることかもしれない。

Mark Slomiany (セッション6) はHA の産生と HA-CD44 シグナリング調節における CD147 (emmprin) の重要な役割に ついて発表した。CD147 と HA-CD44 の分子間相互作用は、 チロシンキナーゼ受容体と薬剤耐性と悪性腫瘍の性質に関連 した輸送体を含む細胞膜複合体の組み立てと安定化に対して 協同的に働くことを示した。フローサイトメトリーを使って CD147 高発現、と低発現の腫瘍細胞を分離することができた。 CD147 高発現の細胞では低発現のものと比較して、より高 度の浸潤性、足場非依存性の成長、薬剤耐性を示した。また CD147 高発現の細胞ではより高いレベルの Has2、CD44、チ ロシンキナーゼ受容体、薬剂輸送体、乳酸輸送体を細胞膜に 発現していた。さらにヒト卵巣がん患者の腹水中から得られ たCD133 陽性のがん幹細胞様細胞でも同様の分子群を細胞表 面に発現していた。CD133 陽性細胞をHAオリゴ糖で処理す ると分子複合体は解離し in vivo での腫瘍増殖が抑制された。

Larry Sherman (セッション9) は HA が神経幹細胞ニッ シに蓄積し CD44 と相互作用することにより前駆細胞の増殖 と分化を調節していることを示した。CD44 欠損マウスでは海 馬性の学習、記憶障害を示し、これは中枢神経系のこの部位 でHA-CD44 相互作用が機能していることを示している。さら に前駆細胞がヒアルロニダーゼを発現しているCNS 損傷部位 に侵入し、ヒアルロニダーゼ分解産物が前駆細胞の増殖と分 化抑制をすることを示した。全体として、神経前駆細胞にお ける HA-CD44 相互作用の重要な働きを示した。

Sophia Khaldoyanidi (セッション9) はヒト胎児性幹細胞 (hESC) 分化経路調節における HA の重要性を示した。hESC 細胞培養系で HA をヒアルロニダーゼで分解すると、造血系 幹細胞、成熟造血系細胞、さらに $\mathrm{C} 31(+)$ 内皮細胞、間質線維 芽細胞様細胞、収縮性筋細胞も減少した。この結果は中肧葉 マーカー mRNA(barachyury、BMP2)、内胚葉マーカー $(\alpha-F P 、$ Sox17) は減少し、外肧葉マーカー (GFAP、FGF5)が増加した ことを示している。

Tonya Caralla（セッション9) は腸骨骨䯣吸引液から得ら れた結合組織前駆細胞 (CTPs) は細胞周囲 HA マトリックスを 持っているが大部分のほかの有核細胞は HA マトリックスを 持っていないと報告した。HA 結合タンパクをコートした磁気 ビーズを使って細胞分画を行った。HA 陽性細胞を 3 回選別す ると、CTP は約 2.7 倍濃縮され、他の有核細胞の大部分が除 
majority of the other nucleated cells. Approximately $80 \%$ of the hematopoietic progenitor cells (HPCs), both myeloid and erythroid, segregated in the first hyaluronan negative fraction with very few remaining in the hyaluronan triple positive fraction. The method provides a clinically useful method for enriching CTPs for bone graft transplants.

Jens Fischer (Session 11) described experiments using 4-methylumbelliferone (MU), an inhibitor of hyaluronan synthesis, in vivo in apoE-deficient mice, a model of atherosclerosis. Hyaluronan concentration in plasma and content in the aortic root were significantly decreased by MU treatment, indicating its effectiveness in inhibiting hyaluronan synthesis. However, contrary to expectations, atherosclerotic indicators were significantly increased after 11 and 21 weeks of treatment with $\mathrm{MU}$ as indicated by increased plaque burden (Oil Red O staining), elevated macrophage content (thioglycolate IP), increased acetylcholine-induced relaxation of aortic rings, increased mean arterial blood pressure, and shorter times to occlusion in thrombotic responses. The effects were specific for atherosclerosis since MU did not alter neointimal hyperplasia responses to ligation of the left carotid artery. A possible mechanism was uncovered by electron microscopy, which revealed severely damaged endothelial cell glycocalyces in myocardial capillaries after MU treatment, which likely increases chronic vascular inflammation and acute inflammatory responses. The results suggest that active steady state hyaluronan metabolism (synthesis and catabolism) is necessary to maintain normal endothelial cell glycocalyx structure and function.

Carlo Ventura (Session 11) demonstrated that injection of hyaluronan mixed esters of butyric and retinoic acid (HBR) into infarcted rat hearts afforded substantial cardiovascular repair and recovery of myocardial performance without the need of stem cell transplantation. The HBR action was associated with an increase in the number of Stro-1positive cells within the injected myocardium. In isolated cardiomyocytes and Stro- 1 stem cells, HBR enhanced not only the transcription of vascular endothelial growth factor, hepatocyte growth factor, $k d r, a k t$, and pim-1, but also the secretion of vascular endothelial growth factor and hepatocyte growth factor. When exposed to HBR, histone H4 acetylation, which involves the activation of a gene program of paracrine patterning for myocardial protection and angiogenesis, significantly increased in those cells. Hyaluronan itself showed much less activity compared to HBR, but the hyaluronan scaffold of HBR appeared to be essential for the expression of the HBR activities.

Paul Bollyky (Session 11) described data showing that large molecular weight hyaluronan can act as a contextual cue in the extracellular matrix of uninjured tissue, which can guide T-cell populations to recognize molecules in their
かれた。赤血球系及び白血球系を含む、約 80\% の造血系前駆 細胞 (HPCs) は、第 1 回目の陰性細胞としてとして選別され、 3 回陽性細胞の中にはほとんど見られなかった。この方法は骨 移植の目的にCTPを濃縮する臨床技術として応用可能である。

Jens Fischer (セッション 11) は 4-MU、HA 合成阻害剂 として知られている、を動脈硬化のモデルである $\mathrm{apoE}$ 欠損マ ウスを使ったin Vivo 実験で報告した。MU 投与により、HA 合成阻害の結果として、血漿中および大動脈基幹部での HA 濃度が減少した。しかしながら、予期に反して動脈硬化を示 す検查值は MU 投与後 11 週、21 週でかえって上昇し、動脈 硬化性プラークの増加 (オイルレッド O 染色)、マクロファー ジ数増加 (thioglycolate IP)、アセチルコリン誘導性の大動脈輪 弛緩上昇、平均動脈圧の増加、血栓性閉塞までの時間短縮な どが見られた。効果はアテローマ性動脈硬化に特異的であり、 左頸動脈結紮に対する非内膜性過形成に変化は見られなかっ た。電子顕微鏡的観察により見られたように、MU 処理後の 心臟の毛細血管における内皮細胞の糖衣が著明に傷害される ことにより慢性的な血管の炎症掞よび急性の炎症反応を引き 起こしたためかもしれない。この結果は、内皮細胞の糖衣を 正常に保つためには定常的な合成と分解を伴った HA 代謝が 必要なことを示唆しているかもしれない。

Carlo Ventura (セッション 11) はHA の酪酸、レチノイ ン酸混合エステル (HBR) を梗塞を起こしたラット心臟に注射 すると幹細胞の移植がなくても明らかな心血管修復、新機能 回復の見られることを報告した。HBRの効果は注射した心筋 内に出現するStro-1 陽性細胞数増加と並行した。単離した心 筋細胞およびStro-1 陽性細胞でHBRは血管内皮細胞成長因子、 肝細胞成長因子、 $k d r 、 a k t 、 p i m-1$ などの転写を充進させただ けではなく、血管内皮細胞成長因子および肝細胞成長因子の 分泌も促進させた。これらの細胞ではHBR を作用させると心 筋保護のための傍分泌的遺伝子発現プログラム充進を伴った ヒストン H4 のアセチル化と血管新生が充進する。 HA のみで はHBR と比較して弱い反応しか引き起こさないが、HA 骨格 の存在は HBR の効果を発揮させるためには必須のものと思わ れる。

Paul Bollyky (セッション 11) は高分子 HA が障害を受 けていない組織の細胞外マトリックスで状況に応じて引き金 となりうることを示した。これにより T 細胞が置かれた環 境の中で免疫学的な反応をすべきでない分子を認識すること 
environment to which they should not react immunologically. High molecular weight HA was shown to induce production of TGF- $\beta$ and an anti-inflammatory cytokine, IL-10, by T cells. Using CD44 null mouse T cells, as well as CD44 antibody blockade, it was shown that this induction was mediated by CD44. The concept was presented that immunologic tolerance can be mediated by high molecular weight HA and this may be achieved via simultaneous crosslinking of multiple CD44 receptors.

Carol de la Motte (Session 12) reported that feeding mice with hyaluronan of MW $\sim 35 \mathrm{kDa}$ (HA-35) protected mice from bacterially induced intestinal inflammation. Data were also presented that showed that intestinal epithelium in vitro and in vivo specifically upregulated expression of antimicrobial peptide $\beta$-defensin 2 protein in response to HA-35, but not to smaller $(\sim 4.7 \mathrm{kDa})$ or larger $(\sim 2000 \mathrm{kDa})$ hyaluronan. HA-35 treated intestinal epithelial cells were also protected from Salmonella infection. It was also reported that human milk contains hyaluronan, which was able to induce expression of $\beta$-defensin 2 protein in epithelium, and its size fell in the range of the HA-35. The data support the model that hyaluronan in milk may provide part of the maternal protection of infants associated with breastfeeding.

Rebecca Heise (Session 12) presented the intriguing concept that mechanical forces can induce a HA-dependent pathway of epithelial to mesenchymal cell transformation (EMT), a process that contributes to fibrosis in many pathological conditions including lung disease. The data presented showed that small molecular weight HA is sufficient to transform alveolar epithelial cells in vitro, and suggested that TLRs and the wnt signaling pathway are critical elements for EMT in mechanically stretched epithelium.

Kenichi Harigaya (Session 12) investigated the role of CD44 in inflammation using a zymosan-induced arthritis model in CD44-deficient mice. In recent years, signaling pathways of TLRs (toll-like receptors) have been shown to initiate innate immune responses linked to a variety of inflammatory diseases, and to have pivotal roles in zymosaninduced arthritis, and zymosan is one of the ligands for TRL2. Their study indicated that CD44 suppresses in vivo inflammation mediated by TLRs via NF- $\varkappa$ B activation, which leads to proinflammatory cytokine production. Furthermore, they showed that CD44 directly associates with TLR2 via its cytoplasmic domain when stimulated by zymosan. Collectively, this report demonstrated that CD44 has a protective role in TLR-mediated inflammation and is the first to demonstrate a direct association between CD44 and a TLR.

Shigeo Shibatani (Session 13) described experiments in which the chlorovirus hyaluronan synthase (cvHAS) gene was stably transfected into tobacco BY-2 cultured cells, which synthesized and secreted hyaluronan continuously. Tobacco
を導くことができる。高分子 HA は T 細胞による TGF- $\beta$ 産 生と抗炎症性サイトカインである IL-10 の産生を増加させる。 $\mathrm{CD} 44$ 欠損マウスの $\mathrm{T}$ 細胞を用いて、あるいは抗 CD44 抗体を 用いて、この誘導がCD44を介していることが示された。免 疫宽容は高分子 $\mathrm{HA}$ を介して抢りさらにこれは同時に複数の $\mathrm{CD} 44$ 受容体のクロスリンキングによるものの可能性があるこ とが議論された。

Carol de la Motte (セッション 12) は分子量約 $35 \mathrm{kDa}$ (HA-35) をマウスに経口投与することにより動物を細菌性腸 炎から保護することができるとの報告をした。In vivoでもin vitro に执いても HA-35 服用により腸上皮での抗菌性ペプチド $\beta$-defensin2 タンパクの発現が増加した。この効果は分子量の 小さな ( 4.7 kDa)HA でも大きな ( 2000 kDa)HA でも見ら れなかった。HA-35 服用後の腸上皮はサルモネラ感染にも抵 抗を示した。ヒト乳汁はHA を含んでいることが知られてお り(分子量はHA-35 と同程度)、これは上皮での $\beta$-defensin2 タンパク発現を誘導することができる。乳汁中 HA は母乳栄 養を通じて幼児を保護するする機構の一部であるかもしれな w。

Kenichi Harigaya ( セッション 12) は炎症における CD44 の役割を、CD44 欠損マウスにおける zymosan 誘起関節炎モ デル使って示した。近年 TLR (toll-like receptors) シグナル伝 達経路は各種の炎症性疾患に関連した自然免疫反応の開始に 関わっていることが示され、zymosan 誘起関節炎 (TRL2 のリ ガンドの一つがである)に拈いても中心的な役割を担ってい ることが知られた。この研究では in vivo で CD44 が NF- $\kappa$ B 活性化(これは炎症促進性サイトカイン産生を引き起こす)に よって TRLが引き起こす炎症を抑制することが示めされた。 さらに著者らはzymosan 刺激時には CD44がその細胞質領域 において TLR2 と直接相互作用を示すことを発表した。まと めると CD44 は TLR を介した炎症性反応において保護的な働 きを持つことと、CD44 がTLR2 と直接相互作用することを初 めて示したものである。

Shigeo Shibatani (セッション 13) はクロロウィルス HA 合成酵素 (cvHAS) 遺伝子をタバコ BY-2 培養細胞に安定的にト ランスフェクトし、この細胞は持続的にHA を合成、分泌した。 タバコ植物に cvHAS と共に L-glutamine-fructose-6-phosphate amido-transferase (GFAT) と UDP-glucose dehydrogenase、 
plants were also stably transfected with cvHAS and cotransfected with L-glutamine-fructose-6-phosphate amidotransferase (GFAT) and UDP-glucose dehydrogenase, key enzymes for synthesis of the HAS substrates, UDP-glcNAc and UDP-glcUA. Hyaluronan was then isolated in substantial quantities from tobacco leaves. Isolation of hyaluronan from tobacco leaves rather than smoking them will definitely improve health.

Connie Tolg (Session 15) described screens of random phage libraries using hyaluronan-Sepharose beads that isolated 65 clones that contained only two peptides, each with amino acids that are present in RHAMM and involved in hyaluronan binding. One of the peptides inhibited RHAMM induction of cell migration in wild type mesenchymal cells but not in RHAMM null mesenchymal cells. The peptide also inhibited macrophage infiltration, blood vessel density and collagen accumulation in an excisional wound healing model, implicating a potential use of the peptides clinically.

Robert Steadman (Session 15) showed data that highlighted a role for the HA pericellular matrix in myofibroblast differentiation and maintenance, a process that contributes to pathologic fibrosis. TGF $\beta$ promotes two mechanisms of myofibroblast differentiation, epithelial to mesenchymal cell transformation and fibroblast differentiation. Myofibroblasts have an extensive hyaluronan pericellular matrix while fibroblasts do not. The evidence presented support a pathway whereby TGF $\beta$, through EGF induction, promotes HAS2 expression as well as hyaluronan production. The hyaluronan, via interaction with CD44, induces smooth muscle actin, a hallmark of myofibroblasts, and EGF receptors, which help maintain the myofibroblast hyaluronan pericellular matrix and therefore the phenotype.

Akira Asari (Session 16) showed that feeding mice that have an autoimmune phenotype (MLR-lpr/lpr) with $900 \mathrm{kDa}$ HA (HA900) led to suppression of the pathological lymph node enlargement and upregulation of the antiinflammatory cytokine, IL-10, as well as decreased expression of inflammatory cytokines. In vitro data identified ways in which HA900 may act. Treatment of intestinal epithelial cell cultures: 1) increased SOCS3, a factor known to decrease inflammatory cytokine effects while promoting anti-inflammatory cytokine production; and 2) decreased pleiotrophin, a factor that can inhibit leukocyte cell death. The data supported a role for TLR4 in the responses to HA900. Large molecular weight HA may be anti-inflammatory, as currently understood, because of its ability to regulate Th1 $\mathrm{T}$ cell responses. The effectiveness of oral administration of HA900 as well as the signaling of intestinal epithelium in vitro implicates the epithelium in control of immune responses.
いずれも HA 合成基質である UDP-glcNAc と UDP-glcUA 生 成のための主要酵素をトランスフェクトし、タバコの葉から かなりの量の HA を抽出することができた。夕バコの葉から HA が生成されるようになれば、喫煙とは違って健康増進に役 立つかも知れない。

Connie Tolg (セッション 15) はランダムファージライブ ラリーをHA-Sepharose ビーズを使ってスクリーニングした ところ 2 種類のペプチドのみを含む 65 のクローンを得ること ができた。これらぺプチドのアミノ酸組成はRHAMM 抢よび これまでに知られている HA 結合アミノ酸配列の一部であっ た。ひとつのペプチドは正常間質細胞に扔ける RHAMM 依存 性細胞移動を抑制したが、RHAMM 欠損間質細胞ではこれが 観察されなかった。このペプチドは切開創治癒モデルにおい てマクロファージの浸潤、血管密度、コラーゲン蓄積を抑制し、 このペプチドの臨床応用可能性を示した。

Robert Steadman (セッション15) は筋線維芽細胞分化に おける細胞周囲 HAの役割を実験的に示した。TGF $\beta$ は筋線 維芽細胞分化に抢ける上皮間葉細胞移行と線維芽細胞分化と

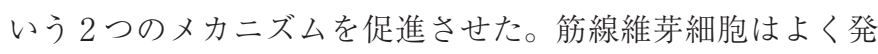
達した HA 細胞外マトリックスを持つが、線維芽細胞はこれ を持たない。TGF $\beta$ は E GF の誘導を通じて HAS2 の発現と HA 産生を促進するというデータが示された。HA C CD44 と の相互作用を介して筋線維芽細胞のマーカーである $\alpha$-smooth muscle actinの発現を促進し、EGF 受容体誘導した(これは 筋線維芽細胞の HA 細胞外マトリックスの維持に役立ち、し たがってその表現型を維持させる)。

Akira Asari (セッション 16) は自己免疫疾患発病傾向の マウス(MLP-lpr/lpr)に分子量約 $900 \mathrm{kDa}$ (HA900) を経口投 与すると、病的なリンパ節肥大を抑制し、抗炎症性サイトカ イン、IL-10、の上昇を抑制すると報告した。また複数の炎症 促進性サイトカイン産生減少が見られた。またIn vitro 実験 でHA900の作用機序を示唆するいくつかの所見が得られた； 自己免疫性動物から得られた T 細胞を HA900 で処理すると SOSC3 (suppressor of cytokine signaling) 誘導が見られた、一 方上皮細胞を処理すると SOSC 3が上昇し、pleiotropin( 白血球 の細胞死を抑制することが知られている) を減少させた。これ はHA900 の作用にTLR4 が関与していることを示唆している。 高分子量 HA は Th1 を介したT 細胞の反応を調節することに より抗炎症作用を発揮しているのかもしれない。HA 経口投与 の有効性、腸上皮の in vitro での HA に対する反応は腸上皮が 免疫反応を調節している可能性を示唆している。 